\title{
MALIGNANT TUMORS OF LATERAL WALL OF THE MESOPHARYNX
}

KAZUHIKO MASHIMA, M. D., ISAMU ONO, M. D., SATOSHI EBIHARA, M. D., HIROO SAITO, M. D., KUNIO SUZUKI, M. D. and WAICHIROU OOYAMA, M. D.

Division of Head and Neck Surgery, Department of Surgical Oncology, National Cancer Center Hospital, Tokyo

CHISATO TAKETA, M. D.

Department of Otolaryngology, Tokyo Medical School, Tokyo

(Director: C. Taketa, M. D.)

Malignant tumors of the mesopharynx are not common among malignant tumors of the head and neck region. The incidence at the National Cancer Center Hospital ( $\mathrm{NCCH}$ ) was 10.6\% (209 out of 1966 patients). From 1962 through 1974, one hundred and five patients with malignant tumor of the lateral wall of the mesopharynx were treated at NCCH. 57 of them were squamous cell carcinoma and 48 were malignant lymphoma.

The male to female ratio was $3.4: 1$ in the patients with sqamous cell carcinoma and the majority of the patients were between 50 and 79 years of age. There was no sex predominance in the patients with malignant lymphoma and they ranged equally from fourth to eighth decade.

The most common symptom was sore throat in cases with squamous cell carcinoma and a mass in the neck in cases with malignant lymphoma.

Radiation therapy was used as the initial treatment in $82 \%$ of the patients with squamous cell carcinoma and in $90 \%$ of the patients with malignant lymphoma. The five-year crude survival rates for the cases with squamous cell carcinoma and malignant lymphoma were $49 \%$ and $56 \%$, respectively.

Squamous cell carcinoma of palatine tonsil were predominantly poorly differenciated type and freaquantly developed cervical lymph nodes metastases. Control of clinically involved cervical lymph nodes is imperative. In the majority of the patients with squamous cell carcinoma from anterior pillar, radiation therapy was done and faild to control the primary site. Surgical treatment should, therefore, be considered. 


\section{中咽頭側壁悪性腫瘍の臨床像}

$$
\begin{aligned}
& \text { 国立がんセンター頭頸科 } \\
& \text { 真島一彦, 小野勇, 海老原敏, 斎藤裕夫, } \\
& \text { 鈴木邦夫,大山和一郎 } \\
& \text { 竹田千里 }
\end{aligned}
$$

はじめに

中咽頭覀性腫瘍は頭颛部癌の中でも頻度は高くない。

国立がんセンターで取り报った頭頸部管腔病 1966例中 わずか、 209例 (10.6\%) 飞すぎない. 従って，われわ れの施設でもどのような悪性腫瑒にはどのような治療法 がよいか迷うことむ少なからずある．各症例ごとに頭を 㥗ませているのが現状である．ことに傊壁型の属平上皮 癌は治療法の選択飞迷うことが多い，そこで，少ない症 例ではあるが自験例を検討して，今後の治療計画の参考

\begin{tabular}{|c|c|}
\hline $\begin{array}{c}\text { 頭頸部管腔腫痬 } \\
\text { 中咽頭悪性腫瘍 }\end{array}$ & $\begin{array}{l}1966 \text { 例 } \\
209 \text { 例 }(10.6 \%)\end{array}$ \\
\hline 対象症例 & 105例 \\
\hline \multicolumn{2}{|c|}{ 側壁原発症例（既治療例老除く） } \\
\hline 屚平上皮癌 & 57 例 \\
\hline 悪泩リンパ腫 & 48例 \\
\hline
\end{tabular}
にしたいと考劣この研究を行った.

\section{1. 研品対象および研究方法}

1962年より1974年までの13年間に国立がえセンター頭
表 1 対象 症例

1962〜1974年, 国立がんセンター

頸科を訪れた中咽頭悪性腫瑒 209例中，未治療の㑡壁 （口蓋扁桃, 前口蓋弓, 後口蓋弓, 舌・扁桃满）悪性腫

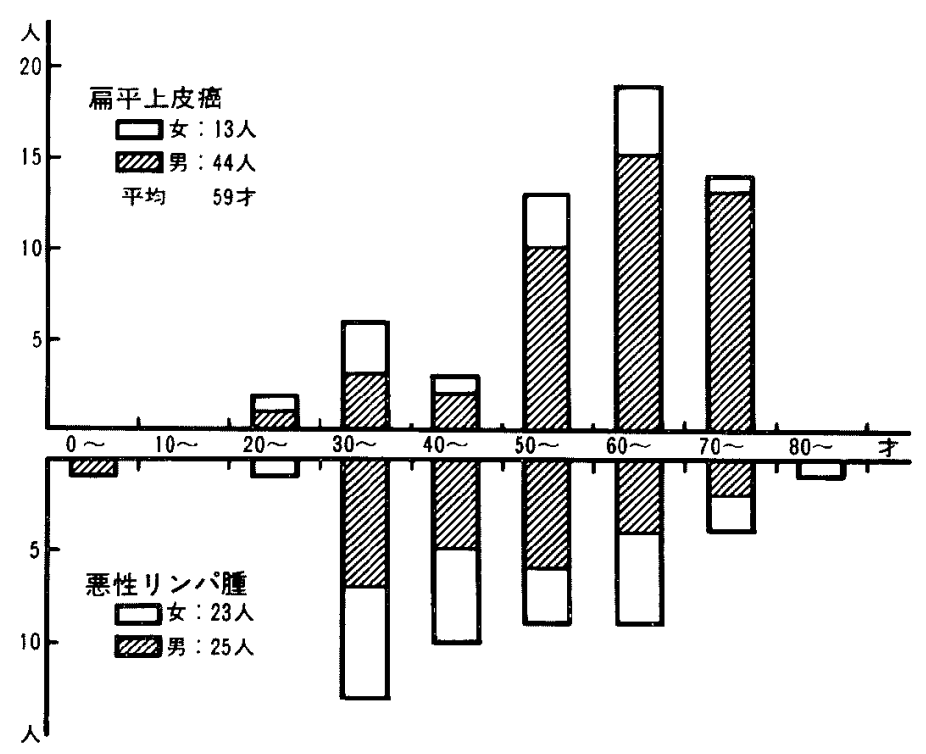

図 1 性・年歯分布 1962 1974年, 国立がえセンター 
瘍であると考えられた症例は105例（需平上皮瘦57例， 悪性リンパ腫 48例) であった。これらの症例を研究対 象とした（表 1).

研究対象の性・年龄分布, 臨休症状, 診断, 㟝断過 程, 発生部位と組織型の関係, TN 分布, 治䍃法と生存 率, 予後と死因などについて険討し文献的に考察した.

\section{2. 結果}

a. 性・年龄分布

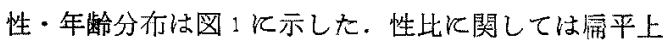
皮癌では 3.4:1 で男性飞多く, 覀性リンパ腫では性差 はみられない，年龄については扁平上皮癌では50歲以上

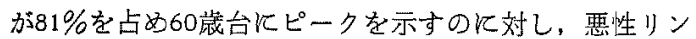
パ腫では50歳以下と50歳以上では略同数で，特沉好発年 台はなく，30歳台以上て平均して発生している。

b. 臨床症状

中咽頭側壁悪性尰笏は種々の初発症状を呈する，一般 K, 炎症性疾患で恃視診上軽度の所見でも自覚症状は比

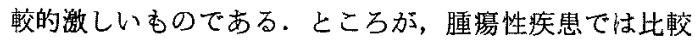
的稻や加炕発症し, 相当大きくなっても案外軽度の自党 症状にとどまることが多い傾向がみられる。初発症状の 頻度忙表 2 亿示した。屚平上皮癌では咽頭痛が 最も多

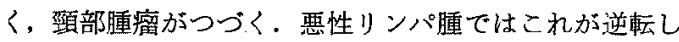
ている.いずれにしても咽頭痛と頚部腫瘤が初発症状と して最も頻度が高い，屚平上皮癌でも頸部腫瘤を初発症 状とする症例が $28 \%$ 亿達することは注目化価する，特に 口蓋珢桃原発の癌脾症例では50\%が頸部腫瘤を初発症状 とし, 悪性りンパ腫と变らない，屚平上皮癌では出血 （菌ブラシが当って出血して気づくことが多い）が初発 症状の症例む 5 例にみられた，悪性リンパ腫では高熱を

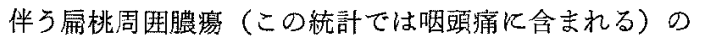
所見分初発症状であ，た症例が 2 例炕みられた。

c. 確定診断までの過程

扁平上皮癌について初発症状が発現してから医師を訪 れるまでの期間（月数）と医師を訪れてから診断確定ま での期間を示したものが表了である。訪れた診療科は必 ずしす耳鼻咽喉科ではなく，内科（咽頭痛の場合が多 い），外科（頸部尰瘤の場合が多い）が多い，始めから 耳異咽喉科医を訪孔る患者はむしる少ない，齿科医師を 訪れるものも少なくない。

初発症状の発現加ら1 力月以内に $50 \% ， 3$ 力月以内江 75\%が医師を訪れている.

医師を訪れてから診断碓定までの期間をみると，66\%
表 2 初発症状 1962 1974年, 国立がれセンター

\begin{tabular}{|c|c|c|}
\hline & 屚平上皮癌 & 两性リンパ腫 \\
\hline 咽頭 痛 & $22(39 \%)$ & $16(33 \%)$ \\
\hline 咽頭腫瘤感 & 9 & 7 \\
\hline 出 血 & 5 & 1 \\
\hline 䁰部腫瘤 & $16(28 \%)$ & $22(46 \%)$ \\
\hline 痛 & 1 & 0 \\
\hline 痛 & 2 & 0 \\
\hline その他 & 2 & 2 \\
\hline 計 & 57 & 48 \\
\hline
\end{tabular}

表 3 屚平上皮癌の初発から診断まで

1962 1974年, 国立驾えセンター

\begin{tabular}{|c|c|c|c|c|}
\hline \multirow[b]{2}{*}{ 月数 } & \multicolumn{2}{|c|}{ 症状初発から訪医まて } & \multicolumn{2}{|c|}{ 訪医から彰断まで } \\
\hline & 症例数 & 確定生存率 & 症例数 & 確定生存率 \\
\hline$\sim 1$ & 28 & $15 / 26$ & 37 & $16 / 32$ \\
\hline$\sim 2$ & 11 & $5 / 10$ & 5 & $1 / 3$ \\
\hline$\sim 3$ & 1 & $2 / 4$ & 1 & $4 / 4$ \\
\hline$\sim 4$ & 2 & $1 / 1$ & 3 & $2 / 3$ \\
\hline$\sim 5$ & 1 & $1 / 1$ & 1 & $0 / 1$ \\
\hline$\sim 6$ & 3 & $2 / 3$ & 2 & $2 / 2^{*}$ \\
\hline $6 \sim 12$ & 4 & $2 / 2$ & 2 & $2 / 2^{*}$ \\
\hline $12 \sim$ & 3 & $1 / 2$ & 2 & $2 / 2^{*}$ \\
\hline
\end{tabular}

$*$ 全例 5 年生存

荘 4 扇平上皮癌の組織型と原発部位

1962 1974年, 国立がんセンター

\begin{tabular}{lccc}
\hline & 前口盖弓 & 口㦈需桃 & その他 \\
\hline 角 化 型 & 27 & 5 & 1 \\
非角化型 & 1 & 23 & 0 \\
\hline
\end{tabular}

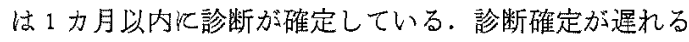
ことはわれわれ医師にとっては不面目なことではある が, 診断確定までに 5 力月以上を要した症例が 6例みら れた. しかし，この6例とも5年健在している。

悪性リンバ偅ではほとえどの症例が初発からろカ月以 内に診断が確定している.

d. 原発部位と組織型

屚平上皮癌症例飞ついて原発部位を门蓋長桃と前口蓋 
引に分けて，組織型との関係をみたものが表 4 である. 夷際にはいずれの部位か判别が困難な症例もみられる が，その場合にはどちらの部位にその容積が多いかをみ きわめていずれかに分類した．これによると口蓋屏桃原 発の症例と前口蓋弓原発の症例ではきわだった病理学的 な差異がみられる、すなわち，前口蓋弓原発の癌はほと んど全例角化型扁平上皮涪であり，口蓋扇桃原発の癌は その $80 \%$ 以上が非用化型屏平上皮癌であった. $(\mathrm{p}<0.01)$

e. TN 分布

屚平上皮癌の TN 分布は表 5 のごときものであった. 初診時頸部リンパ節䎐移の有無についてロ㯼扁桃原発例 と前口蓋弓原発例须検討したものが表 6 である。 口蓋扁挑原発例は $76 \%$ 頸部りンパ節転移を認めたの に対し，前口蓋弓原発例では $29 \%$ あった。すなわち 転移率に有意の差が認められた $(\mathrm{p}<0.01)$ ）な机，口蓋 扁桃ではN3 症例も多い.

覀性リンパ腫の症例を Stage 別 (Ann Arbor の分類) にみたものが表 Zである. Stage II A 症例が最も多く全 症例の $73 \%(35 / 48)$ を占めた.

\section{f 治療法と成綪}

扁平上皮癌症例について行われた一次治療は表 8 の ごとくであった. $82 \%$ 放射線根治照射が試みられてい る. 治療法別の 5 年粗生存率は表 9 のことく放射線治療 単独例では $20 / 38(53 \%)$, 手術単独例では $2 / 2$, 手術と

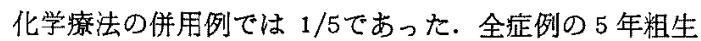
存率は 28/57 (49\%) であった. 口蓋扁桃原発例の5 年 粗生存率は $18 / 29(62 \%)$, 前口蓋弓原発例では $10 / 28$ (36\%) であり口蓋胹桃原発例の生存率は前口荒引原発 例よりも高かった. しかし, 少数例のため両者の閒に有 意差は認められなかった。

表 5 扁平上皮癌の $\mathrm{TN}$ 分布 1962 1974年, 国立がんセンター

\begin{tabular}{crrrrc}
\hline & $\mathrm{N} 0$ & $\mathrm{~N} 1$ & $\mathrm{~N} 2$ & $\mathrm{~N} 3$ & 計 $(\%)$ \\
\hline $\mathrm{T} 0$ & 0 & 1 & 0 & 0 & $1(2)$ \\
$\mathrm{T} 1$ & 4 & 2 & 1 & 1 & $8(14)$ \\
$\mathrm{T} 2$ & 15 & 11 & 1 & 4 & $31(54)$ \\
$\mathrm{T} 3$ & 8 & 4 & 0 & 4 & $16(28)$ \\
$\mathrm{T} 4$ & 0 & 0 & 0 & 1 & $1(2)$ \\
\hline 計 & 27 & 18 & 2 & 10 & $57(100)$ \\
& & 1 & $53 \%$ &
\end{tabular}

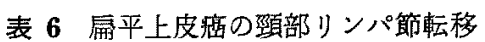
1962 1974年，国立がんセンター

原発巣 症例数 $\mathrm{N}$ 初診時の臨床的転移転移率

$\begin{array}{lrrrrrr}\text { 前口蓋弓・その他 } & 28 & 5 & 0 & 3 & 8 & 29 \% \\ \text { 口蓋 屚桃 } & 29 & 13 & 2 & 7 & 22 & 76 \%\end{array}$

表 7 悪性リンパ腫の病期分類

(Ann Arbor 案による)

1962 1974年，国立がんセンター

\begin{tabular}{rrr}
\hline Stage & I A & 11 \\
& II A & 35 \\
& II B & 2 \\
\hline 㩆 & 48 \\
\hline
\end{tabular}

表 8 屚平上皮㿋飞対する一次治療 1962〜 1974年, 国立がんセンター

\begin{tabular}{lccc}
\hline & 口蓋扁桃 & 前口蓋弓 & 計 \\
\hline 放射線治療単独 & $23(4)$ & $15(2)$ & $38(6)$ \\
根治照射 $\rightarrow$ 手術 & 1 & 8 & 9 \\
手 術 単 独 & 2 & 0 & 2 \\
手術化学寮法併用 & 1 & 4 & 5 \\
姑息的手術のみ* & 2 & 1 & 3 \\
\hline
\end{tabular}

（）は neck dissection

*途中治療拒否など

表 9 肁平上皮癌の 5 年粗生存率

1962 1974年，国立がんセンダー

\begin{tabular}{|c|c|c|c|}
\hline & 口蓋扁桃 & 前口蓋月 & 計 \\
\hline 放射線治療学独 & $14 / 23$ & $6 / 15$ & $20 / 38(53 \%)$ \\
\hline 根治昭射 $\rightarrow$ 手術 & $1 / 1$ & $3 / 8$ & $4 / 9(44 \%)$ \\
\hline 手術治療単独 & $2 / 2$ & 0 & $2 / 2$ \\
\hline 手術化学療法併用 & $0 / 1$ & $1 / 4$ & $1 / 5$ \\
\hline 姑息的手術 & $1 / 2$ & $0 / 1$ & $1 / 3$ \\
\hline 融 & $\begin{array}{c}18 / 29 \\
(62 \%)\end{array}$ & $\begin{array}{c}10 / 28 \\
(36 \%)\end{array}$ & $28 / 57(49 \%)$ \\
\hline
\end{tabular}


表 10 悪性リンパ尰の病期別 5 年粗生存率 1962〜1974年，国立がんセンター

\begin{tabular}{cccc}
\hline Stage & $\begin{array}{c}\text { 放射線治療 } \\
\text { 放射線化学療法併 }\end{array}$ & $\begin{array}{c}\text { 計 } \\
\text { 初治療として })\end{array}$ \\
\hline I A & $10 / 11$ & 0 & $10 / 11$ \\
II A & $13 / 30$ & $2 / 5$ & $15 / 35$ \\
II B & $2 / 2$ & 0 & $2 / 2$ \\
\hline 計 & $25 / 43(58 \%)$ & $2 / 5$ & $27 / 48(56 \%)$ \\
\hline
\end{tabular}

悪性リンパ腫の病期別 5 年粗生存率を表 10 亿示す. Stage I A の粗生存率は 10/11（91\%）であった. 症例 数の多い Stage II A では 15/35 (43\%) と低加った。 全体では 27/48（56\%）であった．この時期の症例では 第一次選択治療として化学療法が行われることははとん どなかった。

\section{g. 予後と死因}

今後の治療成績向上のためにはどのようなことに努力 をはらったらよいかをみるために, 扁平上皮癌症例飞つ いて死亡例の検討を行ったものが表 11 である. 全例 27 例のうち, 死亡時点て原発巣江癌が残存していた症例が 12例（44\%）であった. 頸部リンバ節に残存していたす のを合めると16例 $(60 \%)$ 飞拈よぶ. 特に前口蓝弓原 発の症例は治療不成功の原因のほとんどは原発巣のコン トロールができなかったこと片る。一方，口蓋扁桃原 発例の不成功の原因は原発祭のコントロールの失敗によ ることは少なく，頸部リンパ節あるいは遠隔転移に原因 があることが多い。

他病死 6 例中 4 例は重複癌であった。（胃瘦 2例, 肝 癌 1 例, 食道癌 1 例). 他の 2 例は脳血管障害であった。

悪性リンパ腫の不成功例 21例中 17例は全身化火上る あのであった，他の 4 例中 1 例仙他癌死（食道疾），3
例致死因不明例であった，

\section{3. 考 按}

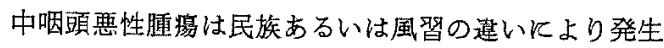
頻度に著しい差がある゙，国立がんセンターでは 全䫝頸

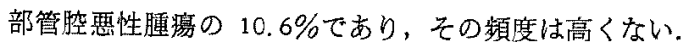

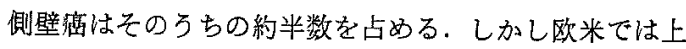

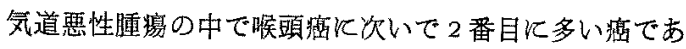
$3^{2)-8)}$.

\section{a , 性・年齢分布}

屚桃癌は男性に多く, 男女比は諸家の報告によって 2.2:1 ないし 5:1 幅がある1) 12)14)。われわれの症 例では男女比は $3.4: 1$ であった，平均年㛔は59歳で60 歳台にピークを示した。これは諸家の報告と一致してい

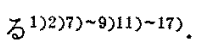

\section{b. 臨木症状}

口蓋屚桃瘦は特徽的な症状を示さないので早期発見が 非常に難しい，患者が自覚するころには隣接䠞器へ進展 している場合が多い，最む頻度の高い症状は明頭痛であ るが，形部腫瘤も注目すべき症状である，悪性リンパ腫 の場合は鼔隆の顕著な状的で愁訴は少ない。しかし， 膨隆方增大寸れば椿音障害, いびきを伴うものもある1

酒, タバコ, 口腔衛生の悪さは中咽頍癌の発症に重要 な役割を果すとされている(12)778)(9).

\section{c. 診断経過}

中咽頭癌は視診可能部位でありながら早期に診断され る例が意外佂少ない，中咽頭は炎症の好発部位であるた め咽頭炎, 扁桃炎, 扁桃肥大症として扱われ頚部転移が

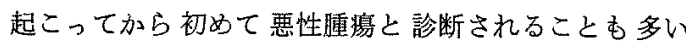
1)7)12)18). Melz $5^{2)}$ の報告では初発症状発現から診断が つくまでの期間は 2 力月未満が多く $(57 \%)$, 平均 3.7 カ月である．Barr $5^{12) 18\rangle}$ は，確定診断までの平均期間 は 5 カ月であり，長いむのは数年に及び，この初期䛦断 の遅れが他の部位の頭頸部癌と比較して，この部位の治 痖成績を悪くしている最大の原因であるとしている。わ 1962 1974年, 国立がんセンター

表 11 扁平上皮站一死亡例の検討

\begin{tabular}{|c|c|c|c|c|c|c|}
\hline & 死秶発夥に残存 & $\begin{array}{l}\text { 原發昱消失 } \\
\text { 部残存 }\end{array}$ & 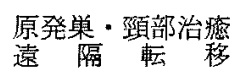 & 他病死 & 不 明 & 計 \\
\hline 口蓋扁桃 & 2 & 4 & 2 & 0 & 1 & 9 \\
\hline 前口蓋弓 & 10 & 0 & 0 & $6^{*}$ & 2 & 18 \\
\hline 娪 & 12 & 4 & 2 & 6 & 3 & 27 \\
\hline
\end{tabular}

* 万ち, 他瘦死 4 例; 食道瘦 1 例, 胃瘦 2 例, 肝癌 1 例, 脳血管障害 2 例 
れわれの症例で山初発症状発現から訪医までの平均期間 は2.4力月, 訪医か方彰断確定までの平均期間は 4.4 力月 である、ここで特街的なこと牥，訪医までの期間と予後 との関係をみると3力月以内医師を訪れた喼者の5年 確定生存率は 55\%であるのに対し，4力月以上の症例で は $78 \% 05$ 年確定生存率を得ている（推計学的飞有意 差はない).このことは奇異にも思えるが，4力月以上の あのは発育が遅い牌であると考光ればその予後が相対的 に良いことはうなずける。志た，診断確定まで5力月 以上を要した 5 症例の内, 全例が 5 年健在しているとい う事実は予後を左右する因子として瘦の性質自身飞よる 要因が大きいことをあのがたっており，Fleming らすの 報告と同じく診断確定の遅れはただちに予後を不良とす るものではないという事実であり，Barr らの報告と逆 の結果が出ている.

一方，悪性リンパ腫では扁平上皮癌症例にみられたよ うな傾向を指摘することは困難であった。しかし, 確定 診断までに 4 力月以上を要した 9 症例中 6 例加 5 年生存 しているという事実はある。これもやはり診断確定が遅 れるよろな症例は発育の荤い腫㾴が多く，またそのよう な症例では全身化する傾向が少ないため，予後がよいむ のとなると推察される。

\section{d. 原発部位と組織型}

屚桃飞原発する中咽頭悪性腫煬の約60\%は悪性りンパ 腫であり，最も多い，次いで低分化型扁平上皮癌であ る。悪性りンパ盾の多くは粘膜下で球形で急速に腫脹 し，口蓋を圧排して口峡部を塞ぐが，深層浸潤はあまり 括こさない。ある時期飞括いて表面の一部が崩壊し潰演 をつくる，その硬度は弾性軟である，低分化型屚平上支 癌は浸潤腫脹型のものが多く，潰瘍形成の傾向は少ない 28).

屚桃癌は中等度ないし高分化型扁平上皮癌が多いとい

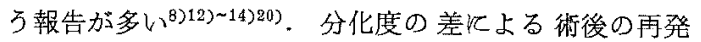
率あるい姑生存率への影響の有無汇関しては, 報告者䎲 より意見がわかれる. Fleming らつ特よび Doyle ら は影翠ありと述べているが, Barrs $b^{12)}$, Chen $b^{13)}$, Perez $5^{143}$ 和よび Chung $5^{20)}$ は影響なしとしてい る.われわれの症例では口蓋扁桃原発瘦は80\%以上が非

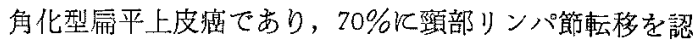
めた。前口蓋原発瘦では非角化型扁平上皮瘦杜 $3.6 \%$ にすぎず残りはすべて角化型屚平上皮癌であり，頸部り ンパ節転移估 $29 \%$ 琶められた。両者の間飞は明らか な差異楒めた。 e. $\mathrm{TN}$ 分布

$\mathrm{TN}$ 分類は UICC 分類, $\mathrm{AJC}$ 分類あるいは施設独自 の分類など 施設により用いられる分類法が暴なってい る.従って，同じ分類を用いた施設と比烄しなければ正 確な比較は出来ない。

し加し，大方の傾向を見るために分類法の差を無視し て諸家の報告を通臨してみると， T1, T2 は平均楼 $62 \%$ $(47 \sim 80 \%)$, T3, T4任平均約 38\% $(29 \sim 53 \%)$ であり, 初診時项部りン八節転移触知例は平均約 56\%（40～64 \%)である237) 911) 13)21) 当院症例では T1, T2 は 70 $\%$ ，T3，T4 は 30\%であり，初彰時頸部りンパ節転移 触知例は $52 \%$ あった。 T1，T2 が若干多い傾向走し たが，症例数が少ないので断定はできない．

f 治療法と成綘

治療成綪を比較する場合，TNM 分類，対象母集団， 治療法, 観察期間, 統計処理の方法が報告者によって違 うので単純に数值のみで比較はでさない，例えば，生存 率の表示には数種頑の方法加あり，同一症例を対象とし た場合です方法の選印により数\%から20\%前後の差が出

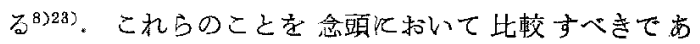
る.

諸家の報告の治療法別反よる成綪捄よびT分類をまと めてみると表 12 のよらになる。われわれの放射線治療 単独の症例は 57 例中 38 例 $(67 \%)$ であり，その5 年粗 生存率は $20 / 38(53 \%)$ である。これを粗生存率を用い た放射線治療例の報告8)112 と比較してみる, われわれ の成䋶の方が主い結果を得ている，他の治療方法は症例 数が少ないので比較出来ない, Barrs $5^{12)}$, Givens $5^{9)}$ の報告では手術治療で良い結果加出ているが, 手術治療 ではT1，T2 が多く，放射線治療単独症例では T3，T4 が多いため，単純治療成續を比ベることはできない。 放射線治療之手術治療の併用療法估各報告とも症例数が 少ないので結論は出をない。

g. 予後を左右する因子

頸部リンパ節転移は生存率老左右する重要な因子であ

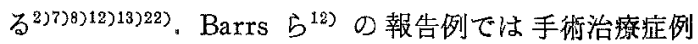
の 5 年生存率鿒部リンパ節の病理組織学的检索所見を もとに比較してみると，軽移陽性のリンパ節なしで 22/ $37(60 \%) ， 1$ ケで $14 / 33(42 \%) ， 2$ ケ以上では 8/30 $(27 \%)$ でる. Chen $b^{132}$ は根本的頚部郭清衔を行っ た症例で, 病理組織学的検索に上り組蟣学的に検索した リンバ節のうちに忶移陽性のリン八゚節がないものは 3 年 生存率が $7 / 10(70 \%)$ であり，蛙移陽性リンパ節が 10 


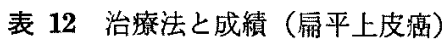

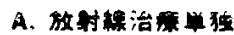

\begin{tabular}{|c|c|c|c|c|c|c|c|}
\hline & 䇺 & $T$ & $T 2$ & T3 & $T 4$ & 生 & 0 \\
\hline \multirow{4}{*}{ 粗 } & Perez:14t & & & & & $38 \%(37 / 97)$ & $\begin{array}{l}3 \text { yrs } \\
\text { tumor tree }\end{array}$ \\
\hline & Cardinale ${ }^{11}$ & $20 \%(13)$ & $35 \%(23)$ & $45 \%(24)$ & $-\cdots$ & $37 \%(24 / 65)$ & \\
\hline & Doyle ${ }^{8)}$ & $26 \%(41)$ & $24 \%(37)$ & $50 \%(77)$ & - & $\begin{array}{l}30 \%(47 / 155) \\
(32 \%) \\
30 \%)\end{array}$ & 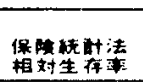 \\
\hline & 国立カんセンター & $16 \%(9)$ & $54 \%(31)$ & $28 \%(16)$ & $2 \%(1)$ & $\begin{array}{l}(49 \%)(28 / 57) \\
53 \%(20 / 38)\end{array}$ & 全症例 \\
\hline \multirow{2}{*}{ 保 } & Barr ${ }^{|2|}$ & & & $37 \%$ & & $25 \%(7 / 29)$ & \\
\hline & Fleming" & & . & & & $57 \%(? / 35)$ & \\
\hline \multirow[t]{2}{*}{ 暴 } & Weller ${ }^{22}$ & $12 \%(17)$ & $38 \%(53)$ & $50 \%(70)$ & - & $32 \%(? / 140)$ & \\
\hline & Doyle & $26 \%(41)$ & $24 \%(37)$ & $50 \%(77)^{\prime}$ & - & $32 \%$ & \\
\hline \multirow{3}{*}{ 定 } & Chen ${ }^{131}$ & $2 \%(1)$ & $42 \%(23)$ & $56 \%(30)$ & - & $20 \%(11 / 54)$ & $\begin{array}{l}3 \text { yrs } \\
\text { cancer free }\end{array}$ \\
\hline & Kaplan ${ }^{21}$ & $12 \%(7)$ & $34 \%(20)$ & $36 \%(21)$ & $18 \%(10)$ & $40 \%(17 / 43)$ & \\
\hline & Givens" & & & 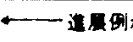 & & $27 \%$ & \\
\hline 相対 & Doyle & $26 \%(41)$ & $24 \%(37)$ & $50 \%(77)$ & - & $38 \%$ & \\
\hline
\end{tabular}

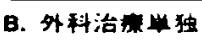

\begin{tabular}{|c|c|c|c|c|c|c|}
\hline 锄 & 国立かんセンター & & & & & $100 \%(2 / 2)$ \\
\hline 保陵 & Barrin & & & $15 \%$ & & $42 \%(34 / 90)$ \\
\hline \multirow[t]{2}{*}{ 灌定 } & Chen ${ }^{131}$ & $9 \%(3)$ & $82 \%(26)$ & $9 \%(3)$ & - & $56 \%(18 / 32)$ \\
\hline & Givens" & 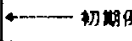 & $\checkmark \longrightarrow$ & & & $87 \%(13 / 15)$ \\
\hline
\end{tabular}

c. Combined Therapy (Planned)

\begin{tabular}{|c|c|c|c|c|c|c|c|}
\hline \multirow{2}{*}{ 軹 } & Malz & $14 \%(5)$ & $44 \%(16)$ & $42 \%(15)$ & - & $64 \%(23 / 36)$ & $\begin{array}{l}2 \text { yrs } \\
\text { tumor troe }\end{array}$ \\
\hline & Perez ${ }^{14 i}$ & & & & & $44 \%(43 / 98)$ & $\begin{array}{l}3 \text { yrs } \\
\text { tumor free }\end{array}$ \\
\hline \multirow{2}{*}{$\begin{array}{l}\text { 保 } \\
\text { 领 }\end{array}$} & Barr ${ }^{12 n}$ & & & $15 \%$ & & $47 \%(9 / 20)$ & \\
\hline & Fleming" & & & & & $35 \%(? / 6)$ & \\
\hline \multirow{2}{*}{$\begin{array}{l}\text { 促 } \\
\text { 定 }\end{array}$} & Chen ${ }^{(3)}$ & $100 \%:(3)$ & & & & $100 \%(3 / 3)$ & $\begin{array}{l}3 \text { yrs } \\
\text { cancer froe }\end{array}$ \\
\hline & Givens ${ }^{91}$ & & & & & $32 \%(7 / 22)$ & \\
\hline
\end{tabular}

D. Combined Therapy(unplanned)

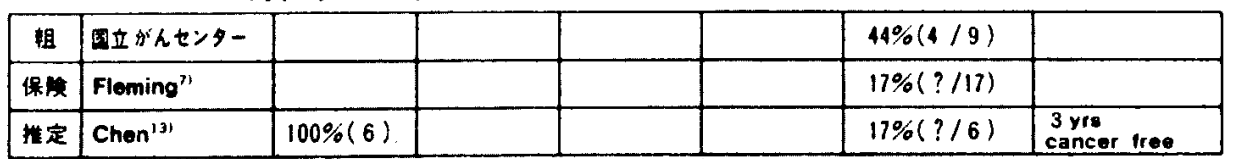

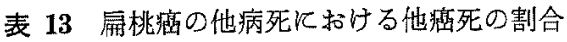

\begin{tabular}{llll}
\hline 報告者 & 他 病 死 & 他 痖 死 & 他癌死/他病死 \\
\hline Fleming et $\mathrm{al}^{7)}$ & $12.3 \%(18 / 65)$ & $6.2 \%(4 / 65)$ & $33 \%(4 / 12)$ \\
Perez et al ${ }^{14)}$ & $30.6 \%(44 / 146)$ & $9.6 \%(14 / 146)$ & $32 \%(14 / 44)$ \\
Givens et al & $21.0 \%(22 / 104)$ & 治療期間中 & \\
国立がんセンター & $10.5 \%(6 / 57)$ & $7.0 \%(4 / 57)$ & $67 \%(4 / 6)$ \\
\hline
\end{tabular}


\%以下では $12 / 18(67 \%) ， 10 \%$ 以上では $0 / 4(0 \%)$ て あったと報告している。

原発巣の大きさが予後に大きな影響を及ぼすと考える 研究者む多(2)811)1422)，Kaplan $5^{21)}$ は $1 \mathrm{~cm}$ 以上の 舌浸潤がある場合, 原発紧は進展例が多く, その予後は 悪いと報告している. Melz $5^{2)}$ む舌浸潤は予後を悪く する因寺であるとしている. Fleming らす 扁平上皮瘦は高分化型に比べて予後が悪いと報告してい る. 5 年生存率はそれぞれ 25\%拈よび 65\%である.ま た，初回治療後も喫煙を続けている患者の予後は悪く， 上気道の 2 次癌発生頻度も高いと述べている。

原桃癌の全経過中に出現する遠隔転移は 9 21\%に認 められる。これは部位による差だけではなく, 前口蓋弓 原発例では角化型扁平上皮癌が多く，口蓋扁桃原発例で は非角化型痌平上皮癌が多いことも関係しているのであ 万弓. Chung $5^{20)}$ は扁桃癌 471 例中 72例 (15\%) 飞遠 隔転移を諗めている. 転移頻度の高小臟器は肺 $42 / 72$ (58\%), 肝 $21 / 72(29 \%)$, 骨 16/72（22\%）であり， 治療開始前扔よび経過観察中同部位をチェックするこ との重要性を強調している.

扁桃癌の死因の中で他病死の占める割合は10〜30.6\% である73913)14)（表 13）。他病死山動脈硬化による心・ 血管障害, 感染症, 全身衰弱などの加疑によるものが多 w.

われわれの症例で他癌死が他病死中に占める割合は67 \%であり，他の報告例の約 2 倍の頻度である。しかし， 全症例に詨する割合は 7\%であり，他の報告例との間保 差は認められない. Givens ら9は他癌死を減少させる ことは扁恌癌の生存率の向上飞さわめて重要でり, 今 後の課題であると言っている，2次原発痹の頻度は頭頸 部領域, 食道, 肺の順飞高( ${ }^{8) 13) 14>22) . ~}$

\section{4. まとめと結論}

1962年より1974年の13年間に国立がんセンター頭頸科 で治療を受けた中胭頭側壁覀性腫滨 105例（扁平上皮癌 57例, 覀性リンハ腫 48例)を対象に性・年齢分布, 臨床 症状，診断，経過，原発部位之組織型の関係，TN 分布， 治療法と生存率, 死因などについて検討した。

主として，扁桃の扁平上皮㶅に関して文献的考察を行 った.

1） 5年粗生存率は扁平上皮癌で $49 \%$, 恶性リンバ連 では 56\%であった.

2）口蓋扁桃に原発する中咽頭覀性腫湯は悪性リンパ
腫が最も多く，76例中 48例（63\%）であった. 次いで 低分化型屚平上皮壆であり，76例中 23例 (30\%) であ った.

扁桃の屏平上皮癌では低分化の㑯向が強く, 頸部リン パ節転移の頻度も高く, 頸部りンパ節転移のコントロー ルが大切である。

3）前口蓋马に原発するすのは分化型扁平上皮腐が多 く，28例中 27 例 $(96 \%)$ であった.

前口蓋弓の扁平上皮癌は局所のコントロールK失敗す ることが多かった. 今後は，手術治療をむっと積䨋的炕 採用する方向炕進むべきすのと考光る。

\section{参文 献}

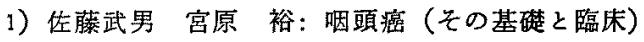
新臨床医学文庫 267，金原出版，東京：61-81， 1977.

2) Maltz R, Shumrick D A, Aron B S and Weichert K A: Carcinoma of the tonsil: Results of combined therapy. Laryngoscope 84: 2172-2180, 1974.

3) Staple T W, Holtz S, Ogura J and Powers W E: Carcinoma of the Tonsil: Missouri Med 62: 909-911, 1965.

4) Ackerman L V and Del Regato J A: Cancer; Diagnosis, Treatment and Prognosis. Mosby, St, Louis, 1962.

5) Seda H J and Snow J B: Carcinoma of the tonsil. Arch Otolaryngol 89: 756-761, 1969.

6) Allen G W and Hemenway W G: Carcinoma of the tonsil. Laryngoscope 70: 246-257, 1960.

7) Fleming $\mathrm{P}$ M, Matz G J, Powell W J and Chen J W: Carcinoma of the tonsil. Surg Clin North Amer 56: 125-136, 1976.

8) Doyle P J, Flores A and Jewett L: Cancer of the tonsil - a retrospective study. J Otolaryngol 7: $189-195,1978$.

9) Givens C D, Johns $M E$ and Cantrell R W: Carcinoma of the tonsil. Arch Otolaryngol 107: 730-734, 1981.

10) Neal C L, Snow J B and Seda H J: An analysis of therapy for Carcinoma of the tonsil. Trans Amer Acad Ophthalmol Otolaryngol 77: 97-104, 1973. 
11) Cardinale F and Fischer J J: Radiation therapy of Carcinoma of the tonsil. Cancer 39: 604$608,1977$.

12) Barrs D M, De Santo $L W$ and O'Fallon W M: Squamous cell carcinoma of the tonsil and tonguebase region. Arch Otolaryngol 105: 479-485.

13) Chen $T Y$, Johnson $R$ and Sako $K$ : Carcinoma of the tonsillar fossa. Cancer of the Head and Neck. Chambers R G, et al. ED. Excerpta Medica, Amsterdam, 1975.

14) Perez C A, Lee F A, Ackerman L V, Ogura $\mathrm{J} H$ and Powers W E: Non randomized comparison of preoperative irradiation and surgery versus irradiation alone in the management of carcinoma of the tonsil. Amer J Roentgenol 126: $248-260,1976$.

15) Andrews P E and Spinkle P M: Carcinoma of the tonsil. South Med J 65: 982-984, 1972.

16) Wang $C$ : Management and Prognosis of Squamous cell carcinoma of the tonsillar region. Radiology 104: 667-671, 1972.

17) Fayos J V and Lampe I: Radiation therapy of carcinoma of the tonsillar region. Amer Rentgenol 3: 85-94, 1971.

18) De Santo L W: Cancer of the posterior oral cavity. Surg Clin North Amer 57: 597-617,
1977.

19) Keane W M, Atkins J P, Wetmore R and Vidas $\mathrm{M}$ : Epidemiology of head and neck cancer. Laryngoscope 91: 2037-2045, 1981.

20) Chung T $S$ and Stefani S: Distant Metastases of tonsillar region: A study of 475 patients. J Surg Oncol 14: 5-9, 1980.

21) Kaplan R, Million R R and Cassisi N J: Carcinoma of the tonsil: Result of radical irradiation with surgery reserved for radiation failure. Laryngoscope 87: 600-607, 1977.

22) Weller S A, Coffinet D R, Goode R L and Bagshaw M A: Carcinoma of the oropharynx. Amer J Roentgenol 126: 236-247, 1976.

23）酒井俊一尾崎正義 池田 寬山本邦之吉田㵓

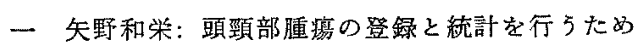
のコンピニータ利用システム 耳鼻 22：25-44, 1976.

24）海老原 解 竹田千里: 中咽頭がえ，竹田千里桶,

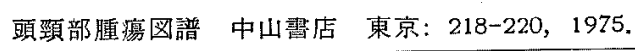

(原稿受付 昭和 $57 ， 6 ， 2$ 日)

別刷請求先 $\bar{T} 113$ 東京都文京区湯島 1-5-45 東京医科业科大学医学部耳舆咽喉科学教室

真島一应 